\title{
Leadership and Motivation to built Morale and Quality of Lecturer's Work
}

\author{
Azis Rachman \\ Sekolah Tinggi Ilmu Administrasi (STIA) Bina Taruna Gorontalo \\ Email Address: \\ *azis.rahman@ubmg.ac.id
}

\begin{abstract}
The four variables presented in this article examine leadership styles, motivation, work spirit, and quality of work for lecturers and teaching staff at private universities in Gorontalo province. This research is an experimental type, where is presented is the result of the analysis and relationship between every variable. The data analysis tool is carried out using the Smart PLS (Partial Least Squares) application. Where the results of this study indicate that leadership style does not directly affect the quality of work. Motivation has a positive and significant effect on work morale. Morale has a positive and significant effect on the quality of work and motivation has a positive and significant effect on the quality of work.
\end{abstract}

Keywords: Leadership Style; Motivation; Work Spirit; Quality of Work.

Abstrak: Empat variabel yang disajikan pada artikel ini mengkaji gaya kepemimpinan, motivasi, semangat kerja serta kualitas pekerjaan pada dosen dan tenaga pendidik di universitas swasta pada provinsi Gorontalo. Penelitian merupakan jenis penelitian eksperimental, dimana yang disajikan adalah hasil analisis pengaruh dan hubungan antar variabel. Alat analisis data dilakukan dengan menggunakan aplikasi Smart PLS (Partial Least Squares). Dimana, hasil penelitian menunjukkan secara langsung, gaya kepemimpinan tidak memengaruhi kualitas pekerjaan. Motivasi memiliki peran positifsignifikan pada semangat kerja. Semangat kerja memiliki peran positif-signifikan dalam meningkatkan kualitas pekerjaan dan juga, motivasi memiliki pengaruh positif-signifikan pada kualitas pekerjaan.

Kata Kunci: Gaya Kepemimpinan; Motivasi; Semagat Kerja; Kualitas Pekerjaan.

\section{INTRODUCTION}

Each university strives to improve the quality of work of each of its lecturers by making various improvements and improvements to the work of lecturers and educators. There are three main pillars included in the tri dharma of higher education, namely the development of the fields of education, research, and community service, which must work in synergy to increase the accreditation of these colleges. Efforts made on an ongoing basis to improve lecturer performance need to be improved through qualifications based on Education, Research, and Community Service standards. Likewise, with the role of the leader in each university, where the pattern of duties and supervision determines the achievement of the university's goals so that in other words, the productivity of the 
organization is determined by the role of the leader of an organization. The leadership applied to several private universities in Gorontalo cannot be said to be entirely reasonable because there are still some unscrupulous leaders who ignore the perfection of the work of their subordinates. The phenomenon that occurs in the field, generally these individuals too readily agree to work results without being based on the lecturers' work's operational standards. Some leaders are also not responsible for what is mandated through their duties as leaders. The phenomenon where they often shift responsibility to other people or, in other words, they do not care about the situation or situation that occurs in the university. Leadership style is a comprehensive pattern of the actions of a leader, both visible and invisible to his subordinates (Rivai, 2009). A consistent combination of the philosophies, abilities, characteristics, and attitudes that underpin an individual's behavior is referred to as a leadership style. Directly or indirectly, the leadership style reflects a leader's belief in his subordinates' abilities. Leadership style is a combination of philosophies, abilities, traits, and attitudes that a leader frequently employs when attempting to influence the performance of his subordinates.

There are two types of leadership styles that are frequently used to solve leadershiprelated problems: transactional and transformational leadership styles. According to (Robbins and Judge, 2015), Transactional leadership emphasizes transactions between leaders and subordinates based on an economic exchange relationship process (exchange of rewards for performance). Transactional leadership emphasizes the importance of motivating and guiding subordinates. Contingent reward, active management by exception, passive management by exception, and laissez-faire are all dimensions of transactional leadership. Meanwhile, the transformational leadership style emphasizes the importance of intellectual stimulation and consideration on an individual level, as well as the importance of charisma and characteristics. This style incorporates elements of charisma, inspirational motivation, intellectual stimulation, and personalized consideration. The appropriate leadership style will be oriented around maximizing work quality; with the appropriate leadership style, employees will be enthusiastic about their jobs and willing to contribute their best efforts.

Regarding the motivation of the lecturers and teaching staff, some leaders also lack the motivation to work optimally; this is due to the low awareness of university leaders who feel that their existence is the primary key to implementing an activity. (Herzberg, 1959) emphasizes intrinsic motivation to increase employee motivation, and extrinsic motivation can lead to employee job satisfaction, impacting employee behavior and performance. In line with (Luthans, 2012) intrinsic motivation is the things that encourage intrinsic achievement, which means that they originate in a person.

Meanwhile, what is meant by extrinsic motivation or maintenance are factors that are extrinsic, which means that they originate from outside the self that also determines a person's behavior in one's life. Another essential factor influencing the quality of work of lecturers and teaching staff at private universities in Gorontalo is morale. The morale of the lecturers and teaching staff greatly influences the continuity of the learning process in the classroom, which affects the quality of graduates. Lecturers and educators who have high morale will work enthusiastically, passionately, full of initiative, full of joy, calm, conscientiousness, likes to work with others, is resilient, steadfast, and never comes late. Meanwhile, those who have low morale will be less enthusiastic at work, lazy, often 
daydreaming, often late or absent from work, often annoying, always alone, and often make mistakes in carrying out tasks (Bafadal, 2003).

(Karhi, 1997) The state apparatus must fulfill the demands of the implementation of services. They must be able to follow the development of society as well as have high professional abilities. Likewise, achieving these goals requires quality resources, material, and human resources (Swastha, 2007). It takes a leader who is able and willing to work together in an organization and has high responsibility and integrity in order to be able to manage existing resources, especially human resources, as the main driving force. (Carmeli et al., 2014) The quality of a leader is often considered the most important factor of organizational success or failure. In general, people consider that the success of an organization is related to the quality and behavior of its human resources both as leaders and subordinates.

Realizing employees who have talent, quality, high motivation, and can work together in teamwork are the keys to success in an organization; therefore, the proper steps are needed for leaders in carrying out their respective duties.

\section{THEORITICAL REVIEW}

A leader is someone who has a plan and who interacts with group members in a particular manner or style. Leadership serves as a dynamic force that inspires, motivates, and coordinates the efforts of the company organization toward a common goal. Leadership is the process of using one's actions to motivate others by leading, guiding, and influencing them to take action to accomplish a goal, (Sutrisno, 2013). Leadership style is a behavioral norm used by a person when that person tries to influence the behavior of others or subordinates (Miftah, 2010). Leadership style is a way for leaders to influence, direct, motivate, and control subordinates in specific ways to complete tasks effectively and efficiently (Siagian and Khair, 2018). The theory that emphasizes change and is the most comprehensive related to leadership is transformational and transactional leadership theory (Bass and Stogdill, 1990). James MacGregor Gurns conceptualized and applied this transformational and transactional leadership style in a political context. This concept was developed further and applied to an organizational context by (Berry and Houston, 1993). (Pawar and Eastman, 1997) argues that transformational and transactional leadership styles can be explicitly classified and that both are in conflict with one another. Every organization requires both transformational and transactional leadership.

The term "motivation" refers to the desire to behave, the direction of behavior/choice, the intensity of behavior/effort, the persistence of behavior/effort, and the actual completion or achievement. (Pintrich and Schunk, 2002). (Anogara, 2000) says that productivity is a universal concept that aims to provide more goods and services to more people by dividing the rewards with input. (Luthans, 2012) workers must motivate themselves to achieve job satisfaction so that it impacts high performance both individually and in groups. Motivation is the provision of the driving force that energizes a person's work in such a way that they are willing to cooperate, work effectively, and are unified in their efforts to achieve satisfaction. (Hasibuan, 2013). According to (Omollo and Oloko 2015), Motivation is critical for a successful organization to ensure that work continues healthily and that the organization survives. Motivation is providing them with the necessary guidance or direction, resources, and incentives to be inspired and interested in working in the manner 
in which they desire. Motivation is the process of initiating behavior, sustaining it, and channeling it into specific action behaviors. Thus, employees are motivated to act by their motives (needs, desires). Work capacity must be matched to the number of people working on it; high levels of motivation can significantly improve work quality.

(Lucio and McNeil, 1979) defines enthusiasm as attitudes and behaviors that indicate a willingness to be involved in the organization and its work. On the other hand, Lucio and McNeil (Bafadal, 2003) interpret morale as attitudes and behaviors that manifest a will brought to school and work. (Bafadal, 2003) emphasized that morale is a manifestation of a person's will through his attitudes and behavior. The difference in willingness will also cause differences in a person's attitude and behavior. Morale can significantly affect the continuity of the entire learning process in the classroom, and in the end, it will also affect the quality of graduates. A lecturer and teaching staff who have high morale have the potential to produce more and better things, a person who has high morale will work enthusiastically, passionately, full of initiative, full of joy, calm, conscientious, likes to work the same as others, tenacious, steadfast, and never late. Conversely, individuals who have low morale will be less enthusiastic at work, lazy, often daydreaming, often late or absent from work, often annoying, always alone, and often make mistakes in carrying out tasks (Bafadal, 2003). High employee morale has been linked to job stability, supportive managers, and defined roles.

In comparison, low morale has been linked to insufficient staffing levels, a high rate of verbal abuse, an increased risk of violence, and workers who feel unappreciated. During the day's work (Bowers et al., 2009); (Totman et al., 2011). (Gilbody et al., 2006) found that educational interventions aimed to improve staff skills and competencies and work-based social support aimed to improve workers' morale in a systematic review of strategies to boost staff morale in mental health settings.

The quality of work (QWL) of a lecturer and teaching staff will significantly affect their performance at universities in Gorontalo, which a leader considers in giving an assessment. (Lagale et al., 2014) The quality of work referred to in this study is that when carrying out the work activity process, a lecturer and teaching staff can show the quality of their human resources by making a maximum contribution to the university where they work. The study of work quality is intended to prompt a person to consider factors that may affect work quality, organizational performance, and, consequently, the university's overall functioning. However, it is critical to define this domain more precisely to develop a core inventory of items that meet these requirements and to compare various groups. (Turcotte, 1988) investigates the problem and defines the QWL program's four primary dimensions. The QWL program encompasses a variety of actions aimed at enhancing worker well-being. The four dimensions are the nature of the work itself, the physical context in which it occurs, the psychosocial context in which it occurs, and the organizational context in which it occurs.

The relationship between transformational leadership and morale refers to research (Werang, 2014). The findings of the data analysis indicate that transformational leadership has a significant effect on teacher morale in Merauke City's public elementary schools. This analysis indicates that the increasing leadership, in this case, the principal's transformational leadership, will be followed by an increase in teacher morale. Other research was also put forward by (Mantja, 2002) where the principal, the elementary school leader, is a source of enthusiasm for teachers and students. The open principal will listen and befriend the teachers 
to work more calmly and happily. The findings of this study corroborate those of an analysis (Nawawi, 1989), which concluded that kinship-based relationships, in addition to rigid formality and autocratic procedures, improve teacher morale. The findings of this study corroborate those of previous research (Masyhud and Tasnim, 2002; Iwantoro, 2006), which demonstrate the influence of leadership, in this case, the principal, on teacher morale.

\section{H1: There is a significant positive effect of leadership style on workplace morale.}

According to (Pintrich and Schunk, 2002), motivation is used to explain the desire to behave, the direction of behavior (choice), the intensity of behavior (continuous effort), and the completion or performance of work. Employee motivation will have a consistent effect on employee morale as a result of the freedom to make morale-enhancing choices. Empirical evidence indicates that motivation is inextricably linked to work morale, with research conducted by (Kusuma, 2016) indicating that work motivation has a positive and significant effect on employee morale at CV. FA Management in Surabaya, where work motivation is a significant factor influencing employee morale at CV. FA Management in Surabaya City. Other research (Marpaung, 2013) indicates that both leadership and motivation variables have a significant impact on the morale of the Siak Regency's Department of Agriculture, Livestock, and Fisheries. If employees have a high level of job motivation, they will be motivated to improve their abilities in planning, implementing, and evaluating work within the organization to achieve the best possible work results through positive work morale.

\section{H2: Motivation has a positive and significant effect on work morale.}

Morale is a picture of a feeling somewhat related to the character/spirit of the group spirit, joy/activity, for groups of workers, indicating the climate and atmosphere of the workers. (Prabu, 2002) Work spirit is the desire and seriousness of a person to do their job well and be disciplined to achieve maximum productivity. (Hasibuan, 2013) It can be concluded that morale is the behavior of employees who work in more optimal conditions to reflect the circumstances in which the company can achieve the expected goals. The study's findings (Dunggio, 2013) indicate that workplace morale has an effect on employee productivity at the PT. Jasa Rahardja (Persero) North Sulawesi branch. The company can increase employee productivity if employees can focus more on completing their work on time and if work time is optimized. Another study (Alwi et al., 2016) used Minitab version 16 portable software to test the hypothesis, with the results indicating a person correlation of 0.361 at the 0.013 level of confidence, indicating a positive correlation between the employee morale variable and organizational effectiveness. However, when the correlation coefficient's interpretation table is used, it is clear that the correlation value is included in the low level of correlation. This indicates that the correlation coefficient between employee morale and organizational effectiveness is "significant," implying that as employee morale improves, the organizational effectiveness of the Makassar Open University's Distance Learning Program Unit will improve as well.

H3: Work Morale has a positive and significant effect on the quality of work. 
By establishing a link between leadership style and work quality (Robbins and Judge, 2015). Leadership is the capacity to persuade a group of people to work toward a common goal, where each organization has predefined goals. Based on these objectives, the leader employs a variety of strategies to persuade groups to accomplish their objectives. Not all leaders possess the same abilities, as they possess a variety of different traits and characteristics. Employee performance is contingent upon the leader, who is responsible for deciding, directing, and supervising his employees. As a result, leadership style plays a critical role in enhancing employee performance. (Dewi and Tarnia, 2019) conducted research on leadership and work quality; based on the results of calculations using the correlation spearman rank and the SPSS application, it was determined that there was a relationship between the general chairman of KSU Tandangsari's leadership style and the cooperative's employee performance. At KSU Tandangsari, partial testing reveals a relationship between leadership style and employee performance with a value of 0.717 ; this indicates a strong relationship between the two variables. This demonstrates that the two have a positive or unidirectional relationship; the more democratic the chairman's leadership style, the higher the employee's performance.

\section{H4: The Leadership Type has a positive and significant effect on the Quality of Work.}

(Armstrong and Kotler, 1996) explains that there is a positive correlation between motivation and employee performance, in that increased motivation results in improved work performance. Improved performance, on the other hand, increases motivation by eliciting feelings of accomplishment. Regardless of how enthusiastic a person is about something, he will be unable to accomplish it if he lacks the necessary skills. According to (Hakim, 2006), one of the factors affecting employee success is motivation. Motivation is a state of mind that encourages an individual to pursue goals or achieve desired outcomes. With sufficient motivation, positive outcomes and high-quality or quality work are possible. This presupposes that increasing employee motivation to complete their work will result in increased productivity/performance. Following the research objectives and the support of several previous researchers, this study will be referred to as the concept of the relationship under consideration, a theoretical and empirical framework that serves as a conceptual framework for a study. According to (Cahyono, 2012) The findings indicate that motivation has a significant effect on the performance of lecturers and employees at Pawyatan Daha University. According to the findings of a study (Hendra, 2020) on the effect of motivation on performance at Tjut Nyak Dhien University, it is stated that $t$ count $t$ table, namely 5,178 1,674 , it is stated that motivation has a partially significant effect on employee performance at Tjut Nyak Dhien University. This means that the higher / better an employee's work motivation is, the higher / better the employee's performance will be; conversely, the lower the employee's work motivation, the lower the employee's performance will be.

H5: Motivation affects the quality of work.

\section{METHODS}

This study's population was composed entirely of Gorontalo province lecturers and teaching staff. Using the Stratified Proportional Random Sampling technique, the Slovin 
formula was used to determine the sample size (Malhotra, 2019). The sample size was described as 236 respondents to ensure that it was representative of 1,569 people with a precision of 6\%. The Stratified Proportional Random Sampling Technique was used to select samples from an existing area that were gradually smaller or larger in size than the existing area.

The questionnaire in this study was compiled using a five-point Likert scale based on an opinion (Singarimbun and Effendi, 2012) which states that the Likert scale is a more systematic way to score the index. This questionnaire consists of 19 indicators. Leadership Style consists of 6 indicators according to the study of (Bass and Stogdill, 1990; Berry and Houston, 1993; Pawar and Eastman, 1997). Work motivation consists of 5 indicators according to the research (Anogara, 2000; Pintrich and Schunk, 2002). Consists of 4 indicators according to the research of (Lucio and McNeil, 1979; Ibrahim Bafadal, 2003; Bowers et al., 2009; Totman et al., 2011). At the same time, the Quality of Work consists of 4 indicators according to the research of (Turcotte, 1988; Lagale et al., 2014; Robbins and Judge, 2015).

\section{RESULTS}

Four primary constructs are illustrated in figure 1, namely the measure variable Leadership Type, Work Morale, Motivation, and Work Quality. Six items assessed Leadership Type, four items assessed Work Morale and Work Quality, and five items assessed Motivation. The testing phase of this study is divided into three stages: To begin, the construct configuration's validity and reliability must be established. Second, the relationship that explains the direct and indirect effects of all variables that were measured.

Table 1 shows that the leadership type construct has an outer loadings value on the TP1 indicator of 0.839 , TP2 of 0.095 , TP3 of 0.010 , TP4 of 0.113 , TP5 of 0.881 , and TP6 of 0.783 . The motivation construct shows the value of outer loadings on the MO1 indicator of $0.899, \mathrm{MO} 2$ of $0.917, \mathrm{MO} 3$ of $0.839, \mathrm{MO} 4$ of 0.269 , and MO5 of 0.231 . The work morale construct shows the value of the outer loading of the MK1 indicator of 0.945 , MK2 of 0.928 , MK3 of 0.867 , and MK4 of 0.651 . Quality of Work construct, outer loadings value on KD1 indicator is $0.892, \mathrm{KD} 2$ is $0.859, \mathrm{KD} 3$ is 0.810 , and KD4 is 0.765 . From the convergent validity results, it is known that there are still outer loadings values $<0.6$, namely TP2, TP3, $\mathrm{TP} 4, \mathrm{MO} 4$, and MO5, where these indicators are invalid, so they are excluded from the model. Meanwhile, indicators with an outer loadings value> 0.6 are valid, so the indicator is valid as a construct measurement.

Table 1. First PLS Model Outer Loading Algorithm

\begin{tabular}{cc}
\hline \multicolumn{1}{c}{ Measurement } & First Outer Loadi \\
\hline 1. Leadership Type (TP) & 0.839 \\
(TP1) & 0.095 \\
(TP2) & 0.010 \\
(TP3) & 0.113 \\
(TP4) & 0.881 \\
(TP5) & 0.785 \\
(TP6)
\end{tabular}


2. Work Morale (MK)

(MK1)
(MK2)
(MK3)
(MK4)

3. Motivation (MO)

(MO1)

(MO2)

(MO3)

(MO4)

(MO5)

4. Quality of Work (KD)

(KD1)

(KD2)

(KD3)

(KD4)
0.945

0.928

0.867

0.652

0.899

0.917

0.839

0.269

0.231

0.892

0.859

0.810

0.766

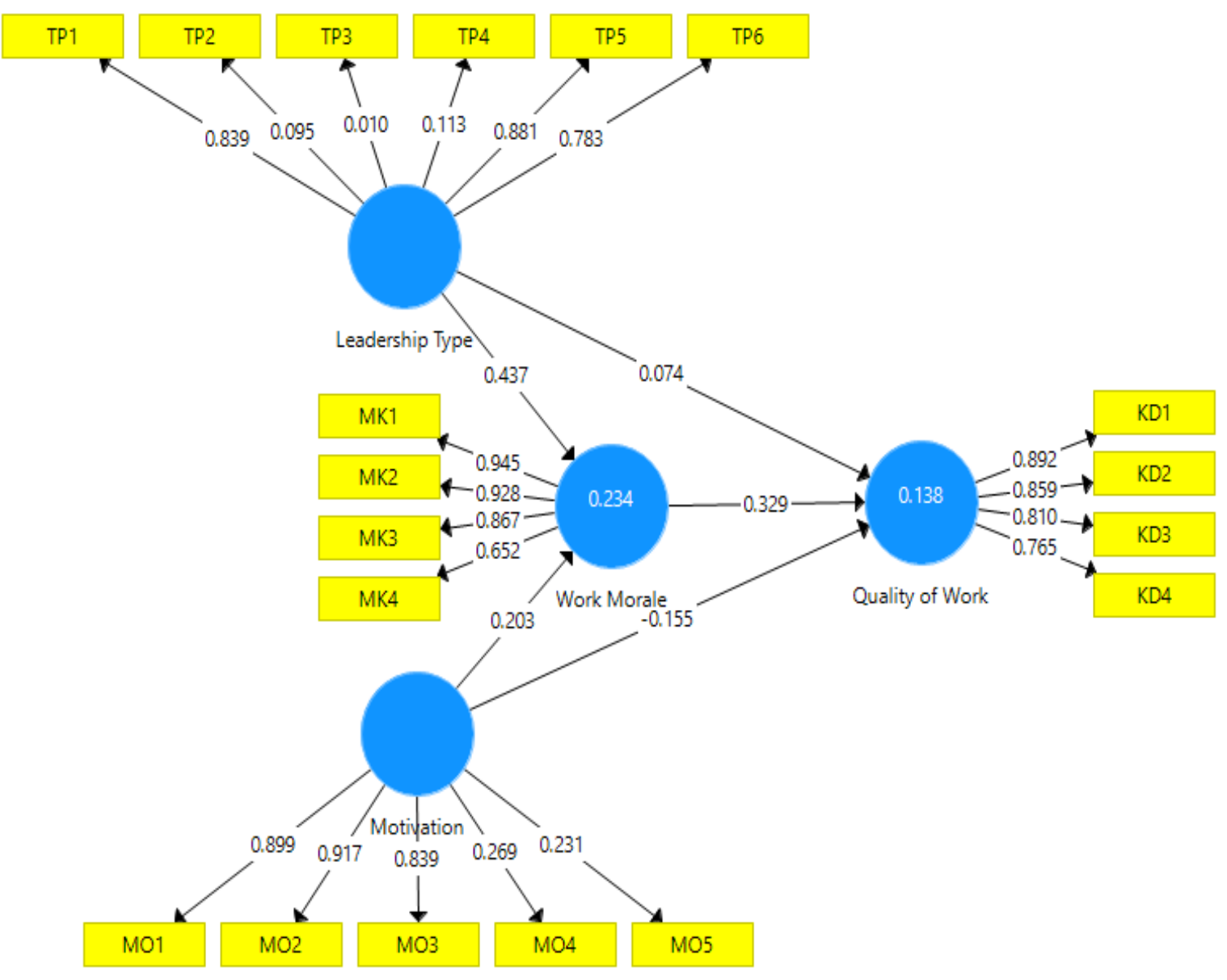

Figure 1. The First Algorithm PLS Model 


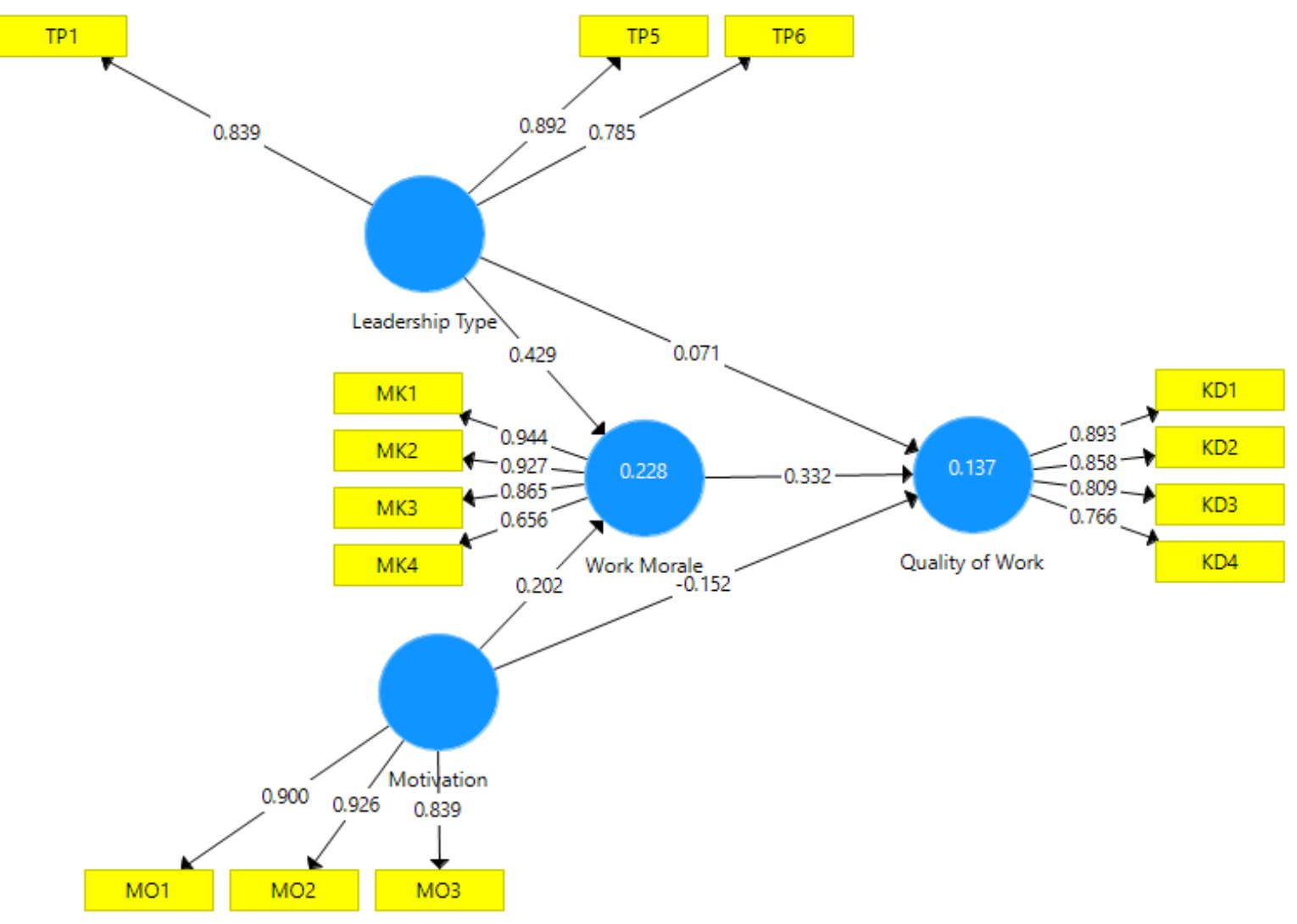

Figure 2. The second algorithm PLS model

As illustrated in Figure 3, all indicators obtain a loading value greater than 0.6, indicating that they are valid as a measure of their construct. A high composite reliability value indicates that each indicator in the latent variable used to measure these variables is extremely consistent. The composite reliability value of greater than 0.7 indicates that the variable has a high degree of internal consistency. Table 2 summarizes the total composite reliability value. 
Table 2. Measurement Table

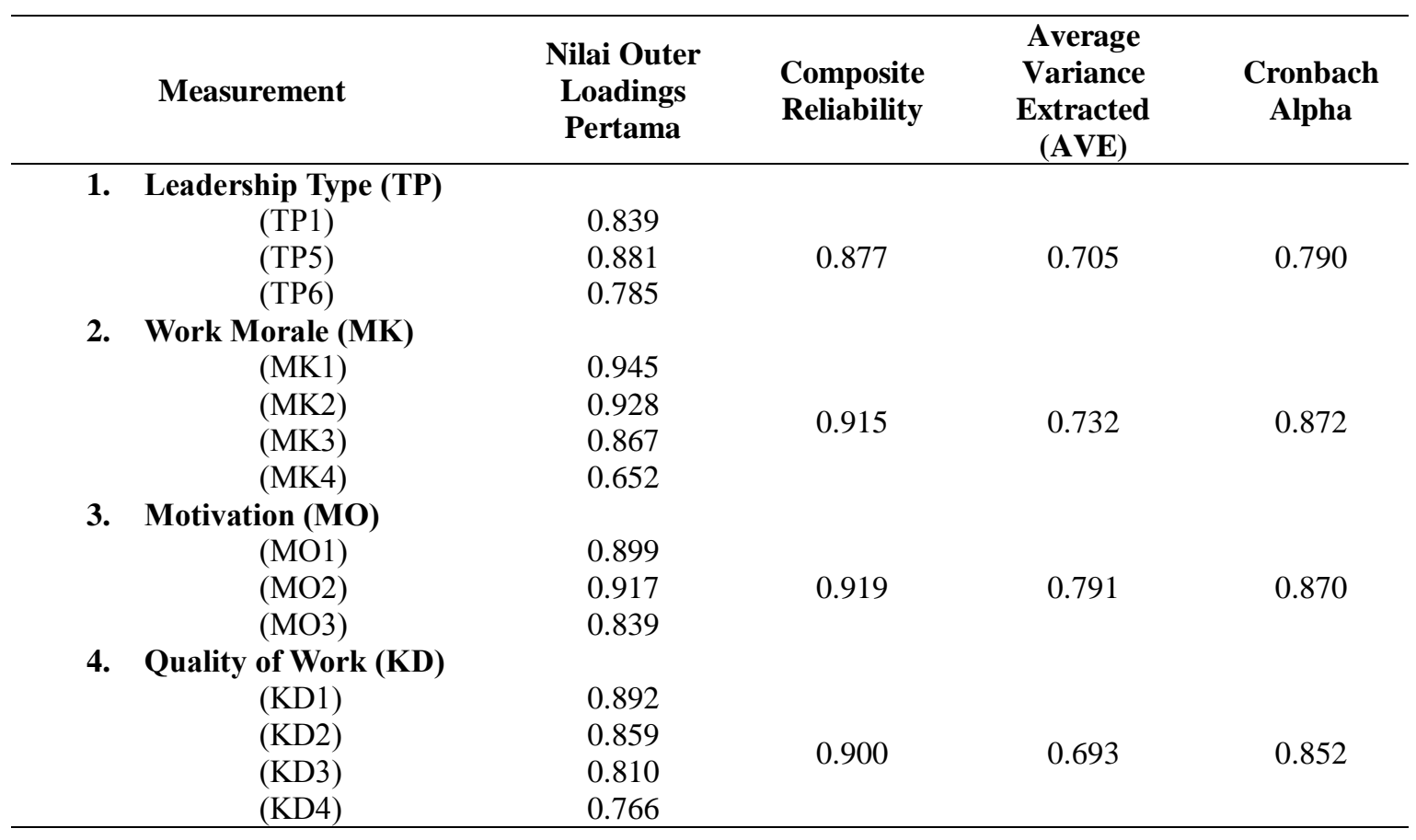

The composite reliability value for the Leadership type construct is 0.877 , Motivation is 0.919 , Work Morale is 0.915 , and Work Quality is 0.900 , as shown in Table 2. The composite reliability value for the four constructs is greater than 0.70 ; this indicates that the constructs have a high degree of internal consistency. The AVE value indicates that the variance of each indicator in the construct derived from these variables is greater than the variance due to measurement errors. AVE value is expected to be greater than 0.5 . The AVE value for the Leadership type construct is 0.705 ; for Motivation, it is 0.791 ; for Work Morale, it is 0.732; and for Work Quality, it is 0.693. Cronbach's alpha value aided in the reliability test's validation. Reliability test alpha Cronbach's $>0.7$ has a limitation. Cronbach's alpha values for the Leadership type construct are 0.790, Motivation is 0.872 , Work Morale is 0.870 , and Work Quality is 0.852 .

To evaluate the structural model, the value of R2, which is the Goodness of the fittest, is used. The Work Morale construct has an R2 value of 0.228 , indicating that the Leadership type can account for 22.8 percent of the variance in the Work Morale and Motivation constructs. By contrast, the remaining 77.2 percent $(100 \%-22.8$ percent) is explained by variables other than those examined. Similarly, the Quality of Work construct has an R2 of 0.137 or 13.7 percent. This value indicates that 13.7 percent of the variance in the Quality of Work construct can be accounted for by the leadership style, motivation, and work morale constructs. By contrast, the remaining 86.3 percent (100\% - 13.7 percent) is explained by unexplored variables. Table 3 summarizes the total $\mathrm{R}$-square value. 
Table 3. Value of R Square

\begin{tabular}{cc}
\hline & R Square \\
\hline Work morale & 0,228 \\
Quality of Work & 0,137 \\
\hline
\end{tabular}

The following test establishes the significance of the influence of independent constructs on the dependent and validates the hypothesis. The test is conducted at a $5 \%$ level of significance; if the t-statistic value is greater than 1.96, the null hypothesis (H0) is rejected. PLS Bootstrapping was used to determine the $t$-statistic value of the latent construct's effective coefficient. Figure 3 illustrates the results of the PLS Bootstrapping Model.

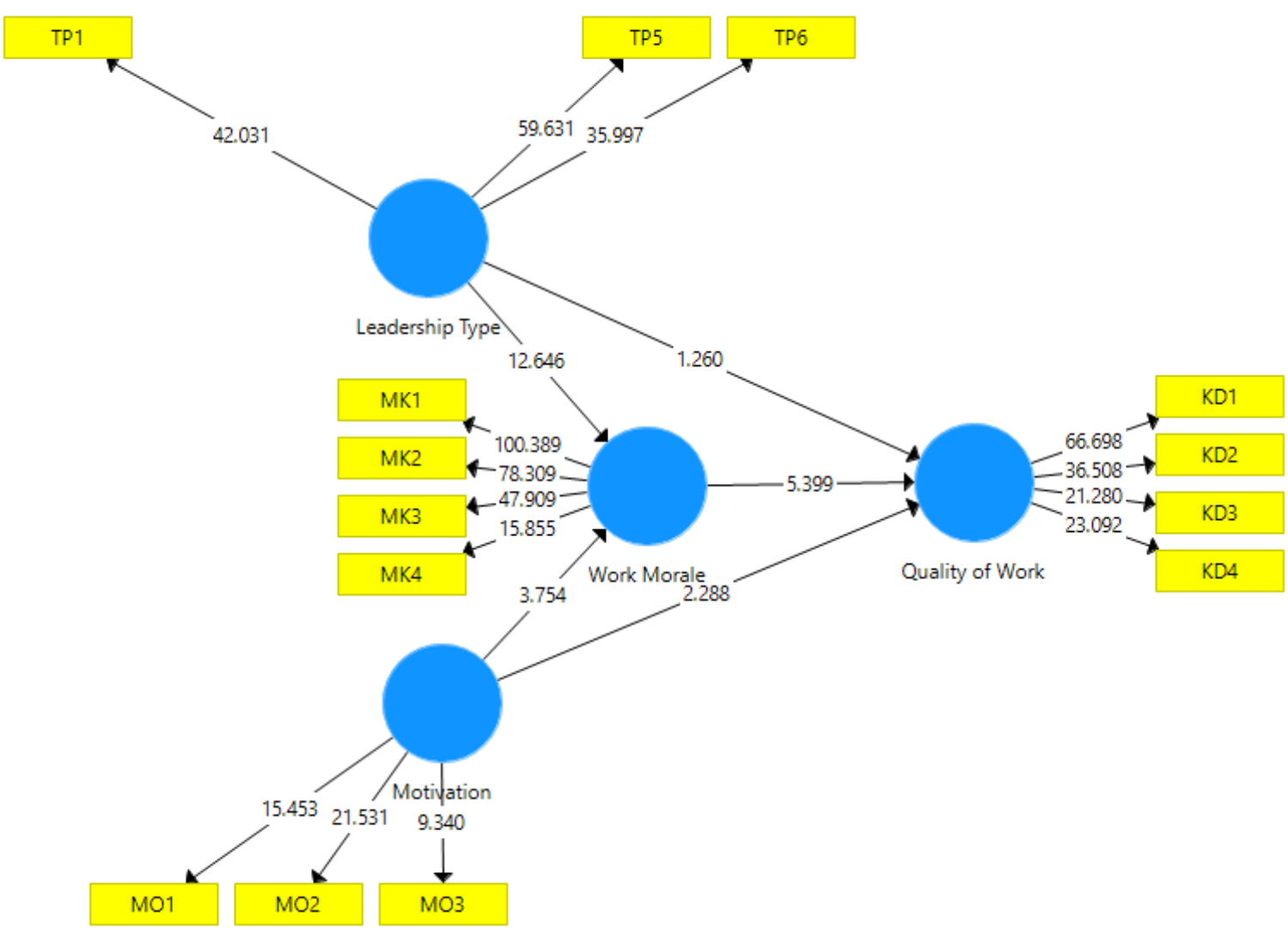

Figure 3. Bootstraping Model

The parameter coefficient's value is displayed in the value (original sample), and the statistical significance value is displayed in table 3. 
Table 4. The Value of the Coefficient (Original Sample), the Standard Error, and the TStatistics

\begin{tabular}{lrrrrr}
\hline & $\begin{array}{c}\text { Original } \\
\text { Sample (O) }\end{array}$ & $\begin{array}{c}\text { Sample } \\
\text { Mean (M) }\end{array}$ & $\begin{array}{c}\text { Standard } \\
\text { Deviation } \\
(\text { STDEV) }\end{array}$ & $\begin{array}{c}\text { T Statistics } \\
(\mid \mathbf{O} / \text { STDEV|) }\end{array}$ & P Values \\
\hline $\begin{array}{l}\text { Leadership Type -> } \\
\text { Quality of Work }\end{array}$ & 0,071 & 0,073 & 0,057 & 1,260 & $\mathbf{0 , 2 0 8}$ \\
$\begin{array}{l}\text { Leadership Type -> } \\
\text { Work Morale }\end{array}$ & 0,429 & 0,431 & 0,034 & 12,646 & $\mathbf{0 , 0 0 0}$ \\
$\begin{array}{l}\text { Motivation -> Quality } \\
\text { of Work }\end{array}$ & $-0,152$ & $-0,152$ & 0,066 & 2,288 & $\mathbf{0 , 0 2 3}$ \\
$\begin{array}{l}\text { Motivation -> Work } \\
\text { Morale }\end{array}$ & 0,202 & 0,205 & 0,054 & 3,754 & $\mathbf{0 , 0 0 0}$ \\
$\begin{array}{l}\text { Work Morale -> } \\
\text { Quality of Work }\end{array}$ & 0,332 & 0,335 & 0,062 & 5,399 & $\mathbf{0 , 0 0 0}$ \\
\hline
\end{tabular}

According to Hypothesis 1, the coefficient of influence of leadership style on work morale is 0.429 , the standard error is 0.034 , and the t-statistic is 12,646 . Accept $\mathrm{H} 0$ if the $\mathrm{t}$ statistic value is $12,646>1.96$. This demonstrates that the leadership style has a positive effect on workplace morale. Hypothesis 2, The effect of motivation on work morale has a coefficient of 0.202 , a standard error of 0.054 , and a t-statistic of 3.754. Accept H0 if the tstatistic value is 3.754> 1.96. This indicates that motivation has a positive effect on workplace morale. According to Hypothesis 3, the coefficient of the effect of work morale on work quality is 0.332 , the standard error is 0.062 , and the t-statistic is 5.399. Accept $\mathrm{H} 0$ if the t-statistic value is 5,399> 1.96. One could argue that workplace morale has a significant impact on work quality. Hypothesis 4: The coefficient for the influence of leadership style on work quality is 0.071 , the standard error is 0.057 , and the t-statistic is 1.260. Because the t-statistic value is 1.2601.96, reject H0. One could assert that leadership style has no discernible effect on the quality of work. The coefficient value for Hypothesis 5 is -0.152 , the standard error is 0.066 , and the $\mathrm{t}$-statistic value is 2.288 . Accept $\mathrm{H} 0$ if the $\mathrm{t}-$ statistic value is $2.288>1.96$. One could assert that motivation has a sizable impact on the quality of work. 
Table 5 summarizes the results of the complete indirect effect coefficient calculation.

Table 5. Indirect Effect

\begin{tabular}{lrrrrr}
\hline & $\begin{array}{l}\text { Original } \\
\text { Sample (O) }\end{array}$ & $\begin{array}{l}\text { Sample } \\
\text { Mean (M) }\end{array}$ & $\begin{array}{l}\text { Standard } \\
\text { Deviation } \\
(\text { STDEV) }\end{array}$ & $\begin{array}{l}\text { T Statistics } \\
(\mid \text { O/STDEV|) }\end{array}$ & P Values \\
\hline $\begin{array}{l}\text { Leadership Type -> } \\
\text { Work Morale -> Quality } \\
\text { of Work }\end{array}$ & 0,142 & 0,145 & 0,031 & 4,606 & $\mathbf{0 , 0 0 0}$ \\
$\begin{array}{l}\text { Motivation -> Work } \\
\begin{array}{l}\text { Morale -> Quality of } \\
\text { Work }\end{array}\end{array}$ & 0,067 & 0,069 & 0,022 & 3,036 & $\mathbf{0 , 0 0 3}$ \\
\hline
\end{tabular}

According to Table 5, the effect of leadership style on work morale is 0.142 , the standard error is 0.031 , and the t-statistic value is 4.606 . Accept $\mathrm{H} 0$ if the t-statistic value is 4.606> 1.96. One could assert that leadership style has a significant impact on the Quality of Work via workplace morale. Motivation has a 0.067 effect on the Quality of Work via work morale, with a standard error of 0.022 and a t-statistic value of 3.036. Accept $\mathrm{H} 0$ if the t-statistic value is 3.036> 1.96. Through work morale, motivation has a significant effect on the Quality of Work.

\section{DISCUSSION}

This study's leadership style is defined by a series of declarative indicators that encompass both transformational and transactional leadership theories (Bass and Stogdill, 1990). Both transformational and transactional leadership styles can be explicitly classified, and both conflict with one another. Every organization requires both transformational and transactional leadership. The findings of the inner model analysis indicate that this variable has the potential to influence workplace morale. This research supports the findings of (Werang, 2014), (Mantja, 2002), (Nawawi, 1989), (Masyhud and Tasnim, 2002), and (Iwantoro, 2006) that a family-centered relationship, regardless of its rigid formality and autocratic procedural rules, has a positive effect on teacher morale.

The motivation theory in this study applied from (Pintrich and Schunk, 2002), which states that motivation is used to explain the desire to behave, the direction of behavior (choice), the intensity of behavior (constant effort), and completion or work performance. Employee motivation will have a consistent effect on employee morale as a result of the freedom to make morale-enhancing choices. Motivation has a significant positive effect on work spirit, as demonstrated by the test results. The findings of this study add to the empirical evidence that motivation is closely related to work morale, as demonstrated by research conducted by (Kusuma, 2016; Marpaung, 2013). They will be motivated and strive 
to improve their planning, implementation, and evaluation of the organization's work to achieve maximum work results while maintaining a positive work environment.

Morale is a term that refers to a feeling that is somewhat related to the character/spirit of the group, joy/activity, and is used to describe groups of workers. It also refers to the climate and atmosphere of the workers. (2002, Prabu) Work spirit refers to an individual's desire and commitment to perform their job well and to be disciplined to achieve maximum productivity. The study's findings indicate that morale has a significant positive effect on work quality. (Hasibuan, 2013) based on the spirit of work, it can be concluded that employees who work in more optimal conditions reflect the conditions under which the business can achieve its objectives. The findings of this study corroborate prior research (Dunggio, 2013; Alwi et al., 2016) that demonstrates a positive correlation between employee morale and organizational effectiveness.

(Robbins and Judge, 2015) introduced a leadership style based on work quality, where leadership is defined as the ability to influence a group toward achieving goals. Each organization has predetermined goals, and the leader uses various methods to influence groups within the organization toward achieving those goals. This study indicates that the influence of leadership style on the quality of work is negligible. The findings of this study contradict those of (Dewi and Tarnia, 2019), indicating that the relationship between these two variables is strong and indicates a positive or unidirectional relationship between them. Thus, the more democratic the chairperson's leadership style, the higher the employee's performance.

(Armstrong and Kotler, 1996) explains that there is a relationship between motivation and employee performance that is beneficial in the sense that increased motivation results in improved work performance, and vice versa, improved performance results in increased motivation due to feelings of accomplishment. Regardless of how enthusiastic a person is about something, he will be unable to accomplish it if he lacks the necessary skills. The study's findings indicate that motivation has a positive and significant effect on the quality of work or performance of Gorontalo City lecturers and teaching staff. This research reinforces the findings of (Cahyono, 2012) and (Hendra, 2020) regarding the effect of motivation on performance, namely that the higher / better the work motivation of employees, the higher / better the quality of work or performance of lecturers and educators in Gorontalo City.

\section{CONCLUSION}

The leadership style of lecturers and teaching staff at private universities in Gorontalo City has no direct effect on the quality of their work. This study demonstrates that the leadership style employed thus far has failed to inspire and motivate all lecturers and teaching staff at Gorontalo City's private universities. The influence of leadership style on morale has a positive and significant effect on the coefficient value. The coefficient of motivation on morale indicates that it has a positive and significant effect on morale. The spirit variable has a significant positive effect on work quality. Simultaneously, the motivation variable has a significant positive effect on the quality of work.

Managerial Implication. Management can take advantage of a combination of variables in this study. These findings can be used as input to leaders of private universities in Gorontalo 
City as a guideline for developing the quality of Human Resources (HR) in their capacity as a provider of encouragement towards improving organizational behavior to be enthusiastic at work. By positively improving the leadership style periodically and continuously, the implementation of the leadership style has shown high results on the performance or quality of work of lecturers and educators at private universities in Gorontalo City.

Theoretical Implications. Motivation and morale have a positive and significant effect on the quality of work, as evidenced by test results. The findings of this study add to the theory and prior research by demonstrating that increased motivation and morale have an effect on the performance of lecturers and teaching staff at the Private University of Gorontalo City. Directly, leadership style does not affect employee performance. The findings of this study are highly incongruent with established theoretical concepts, as leadership styles should be capable of improving performance and altering an individual's behavior at work.

\section{REFERENCES}

Alwi, M., Sylvana, A., dan Risnashari. (2016). Pengaruh semangat kerja pegawai terhadap keefektifaan organisasi unit program belajar jarak jauh Universitas Terbuka Makassar. Jurnal Analisis Dan Pelayanan Publik, 2(1), 31-46.

Anogara, S. (2000). Manajemen Sumber Daya Manusia. Bumi Aksara.

Armstrong, dan Kotler. (1996). Dasar-Dasar Pemasaran. Intermedia.

Bafadal, I. (2003). Peningkatan profesionalisme guru sekolah dasar dalam kerangka manajemen peningkatan mutu berbasis sekolah. Bumi Aksara.

Balthazard, P. A., Cooke, R. A., and Potter, R. E. (2006). Dysfunctional culture , dysfunctional organization Capturing the behavioral norms that form organizational culture and drive performance. Journal of Managerial Psychology, 21(8), 710-732. https://doi.org/10.1108/02683940610713253

Basalamah, J., Syahnur, M. H., and Basalamah, A. (2020). Recruitment And Selection Practice On Indonesia State-Owned Enterprise: A Literature Review. Manajemen Bisnis, 10 (2).

Bass, B. M., \& Stogdill, R. M. (1990). Theory, research, and managerial applications. Simon and Schuster.

Bernardin, and Russel. (2002). Organizations: Behavior, Structure, Processes, Fourteenth Edition. Mc Grow Hill.

Bohlander, G., Snell, S., and Sherman, A. (2001). Managing Human Resource (12th Editi).

Bowers, L., Allan, T., Simpson, A., Jones, J., and Whittington, R. (2009). Morale is high in acute inpatient psychiatry. Social Psychiatry and Psychiatric Epidemiology, 44(1), 39-46. https://doi.org/10.1007/s00127-008-0396-z

Cahyono, A. (2012). Analisa Pengaruh Kepemimpinan, Motivasi dan Budaya Organisasi terhadap Kinerja Dosen dan Karyawan di Universitas Pawyatan Daha Kediri. Jurnal Ilmu Manajemen Revitalisasi, 1(1), 283-298.

Carmeli, A., Sheaffer, Z., Binyamin, G., Reiter-Palmon, R., and Shimoni, T. (2014). Transformational leadership and creative problem-solving: The mediating role of psychological safety and reflexivity. Journal of Creative Behavior, 48(2), 115-135. https://doi.org/10.1002/jocb.43 
Chamariyah, Sudiro, A., Noermijati, and Rofiaty. (2015). The Effect of Transformational Leadership to Organizational Citizenship Behavior (OCB) and Employees' Performance (Study Case to PT. PLN (Persero) Pamekasan Area). International Journal of Business and Behavioral Sciences, 5(4).

Dewi, R. R., dan Tarnia, T. (2019). Pengaruh kinerja keuangan terhadap nilai perusahaan dengan good corporate governance sebagai variabel moderasi. Jurnal Informasi, Perpajakan, Akuntansi, Dan Keuangan Publik, 6(2), 115-132.

Dunggio, M. (2013). Semangat Dan Disiplin Kerja Terhadap Produktivitas Kerja Karyawan Pada Pt. Jasa Raharja (Persero) Cabang Sulawesi Utara. Jurnal Riset Ekonomi, Manajemen, Bisnis Dan Akuntansi, 1(4), 523-533.

Ghashghaeinia, A. R., and Hafezi, S. (2015). Relationship between organizational culture and organizational citizenship behavior among personnel of Islamic Azad University of Fars. Journal of Applied Environmental and Biological Sciences, 5(11S), 131-138.

Gilbody, S., Cahill, J., Barkham, M., Richards, D., Bee, P., and Glanville, J. (2006). Can we improve the morale of staff working in psychiatric units? A systematic review. Journal of Mental Health, 15(1), 7-17. https://doi.org/10.1080/09638230500512482

Hair, J., Black, W., Babin, B. J., and Anderson, R. E. (2009). Multivariate data analysis. Prentice Hall.

Hakim, A. (2006). Analisis Pengaruh Motivasi, Komitmen Organisasi Dan Iklim Organisasi Terhadap Kinerja Pegawai Pada Dinas Perhubungan Dan Telekomunikasi Provinsi Jawa Tengah. JRBI, 2(2), 165-180.

Harwiki, W. (2013). Influence of Servant Leadership to Motivation, Organization Culture, Organizational Citizenship Behavior (OCB), and Employee's Performance in Outstanding Cooperatives East Java Province, Indonesia. IOSR Journal of Business and Management, 8(5), 50-58.

Hasibuan, M. S. P. (2013). Manajemen Sumber Daya Manusia (Tujuh Bela). Bumi Aksara. Hendra. (2020). Pengaruh Budaya Organisasi, Pelatihan Dan Motivasi Terhadap Kinerja Karyawan Pada Universitas Tjut Nyak Dhien Medan. Maneggio: Jurnal Ilmiah Magister Manajemen, 3(1), 1-12. https://doi.org/10.30596/maneggio.v3i1.4813

Herzberg, Frederick, E. (1959). The Motivation to Work. John Wiley \& Sons, Inc.

Huei, T. Y., Naha, N., Mansor, A., and Tat, H. H. (2014). Role of OCB and demographic factors in the relationship of motivation and employee performance Role of OCB and Demographic Factors in the Relationship of Motivation. Intangible Capital, 10(3), 425-447. https://doi.org/10.3926/ic.435

Ibrahim Bafadal. (2003). Peningkatan profesionalisme guru sekolah dasar dalam kerangka manajemen peningkatan mutu berbasis sekolah. Bumi Aksara. https://scholar.google.com/scholar?cluster=8237676160081926631\&hl=en\&oi=scho larr

Iwantoro. (2006). Kompetensi Kekepalsekolahan dalam Hubungannya dengan Semangat Kerja Guru SD Negeri di Kabupaten Mojokerto. Universitas Negeri Malang.

Jain, A. K. (2015). Volunteerism and organisational culture Relationship to organizational commitment. Cross Cultural Management An International Journal, 22(1), 116-144. https://doi.org/10.1108/CCM-11-2013-0167

Karhi, N. S. (1997). Beberapa Catatan Tentang Good Governance. Vurnal Administrasi Dan Pembangunan, 1(2). 
Kusuma, Y. W. (2016). Pengaruh Motivasi Kerja Dan Insentif Terhadap Semangat Kerja Karyawan Cv. F.A Management. Jurnal Ilmu Dan Riset Manajemen, 5(2).

Lagale, D. G., Mekel, P. A., dan Sepang, J. L. (2014). Pelatihan, Disiplin Kerja Dan Kualitas Kerja Terhadap Prestasi Kerja Pada Pt. Pln (Persero) Area Manado. Jurnal Riset Ekonomi, Manajemen, Bisnis Dan Akuntansi, 2(2), 935-943. https://doi.org/10.35794/emba.v2i2.4440

Lucio, W. H., and McNeil, J. D. (1979). Supervision in Thought and Action. Mc Grow Hill. Luthans, F. (2012). Perilaku Organisasi. Andi.

Malhotra, N. K. (2019). Marketing Research: An Applied Orientation, 7th Edition. Pearson. Mantja, W. (2002). Manajemen Pendidikan dan Supervisi Pengajaran. Elang Mas.

Marpaung, R. (2013). Pengaruh Kepemimpinan Dan Motivasi Terhadap Semangat Kerja Pegawai Dinas Pertanian, Peternakan Dan Perikanan Kabupaten Siak. Jurnal Ekonomi Universitas Riau, 21(02), 8692.

Maryam Azar, and Shafighi, A. A. (2013). The Effect of Work Motivation on Employees' Job Performance (Case Study: Employees of Isfahan Islamic Revolution Housing Foundation). International Journal of Academic Research in Business and Social Science, 3(9).

Masyhud, M. S., dan Tasnim, Z. (2002). Pengaruh Kepemimpinan Kepala Sekolah dan Iklim Organisasi Sekolah Terhadap Pelibatan Guru dalam Pengambilan Keputusan, Semangat Kerja Guru dan Kedisiplinan Siswa pada Sekolah Dasar di Wilayah Eks Keresidenan Besuki.

Miftah, T. (2010). Perilaku Organisasi. Raja Grafindo Persada.

Mohamed, A. I., and Abukar, A. A. S. (2013). The Impact of Organizational Culture on Employees Performance Of Mogadishu Universities. Academic Research International, 4(6).

Mohammadreza Moradi. (2015). Modeling the Relationship between Work Motivation and Employees Organizational Citizenship Behaviors of Youth and Sport Offices in Chaharmahal and Bakhtiari Province. Russian Federation European Journal of Physical Education and Sport, 7(1), 59-67.

Mushtaq, K., Ashfaq Ahmed, M., and Ullah Warraich, S. (2014). A Study on Job Satisfaction, Motivation and Organizational Citizenship Behavior. International Journal of Management Sciences and Business Research, 3(11), 1-12.

Nasir, M., Taufan, R. R., Fadhil, M., dan Syahnur, M. H. (2021). Budaya Organisasi Dan Disiplin Kerja Serta Pengaruhnya Terhadap Kinerja Karyawan. AkMen JURNAL ILMIAH, 18(1), 71-83.

Nawawi, H. (1989). Administrasi Pendidikan. Gunung Agung.

Nurun Nabi, M., Monirul Islam, M., Mahady Dip, T., and Abdullah Al Hossain, M. (2017). Arabian Journal of Business and Impact of Motivation on Employee Performances : A Case Study of. Arabian Journal of Business and Management Review, 7(1), 1-8. https://doi.org/10.4172/2223-5833.1000293.

Omollo, P. A., and Oloko. (2015). Effect of motivation on employee performance of commercial banks in Kenya : A case study of Kenya Commercial Bank in Migori County. International Journal of Human Resource Studies, 5(2), 87-103.

Organ, D. W. (1998). Organizational Citizenship Behavior: The good soldier syndrome (Lexington,). 
Pintrich, P. R., and Schunk, D. H. (2002). Motivation in Education Theory,. Research, and Applications 2nd Edition. Merril Prentice Hall.

Podsakoff, P. M., Mackenzie, S. B., Paine, J. B., and Bachrach, D. G. (2000). Organizational Citizenship Behaviors: A Critical Review of the Theoretical and Future Research. Journal of Management, 26(3), 513-563.

Prabu, M. A. (2002). Manajemen Sumber Daya Manusia. PT. Remaja Rosda Karya.

Riani, A. L. (2011). Budaya Organisasi (Pertama). Graha Ilmu.

Rivai, V. (2009). Manajemen Sumber Daya Manusia Untuk Perusahaan: Dari Teori ke Praktek. PT Rajagrafindo Persada.

Robbins, S. P., dan Judge, T. A. (2015). Perilaku Organisasi Organizational Behavior 16/E (R. Saraswati \& F. Sirait (eds.); 16th ed.). Salemba Empat.

Shahzad, F. (2014). Impact of organizational culture on employees' job performance An empirical study of software houses in Pakistan. International Journal of Commerce and Management, 24(3), 219-227.

Siagian, T. S., dan Khair, H. (2018). Pengaruh Gaya Kepemimpinan Dan Lingkungan Kerja Terhadap Kinerja Karyawan Dengan Kepuasan Kerja Sebagai Variabel Intervening. Jurnal Ilmiah Magister Manajemen, 1(1), 59-70. https://doi.org/10.30596/maneggio.v1i1.2241.

Singarimbun, M., dan Effendi, S. (2012). Metode Penelitian Survai. LP3ES.

Sloat, K. C. M. (1999). “Organizational Citizenship.” Professional Safety.

Sutrisno, E. (2013). Manajemen sumber daya manusia. Kencana Prenada media group.

Swastha, B. (2007). Manajemen Pemasaran Modern. Liberty Offset.

Totman, J., Hundt, G. L., Wearn, E., Paul, M., and Johnson, S. (2011). Factors affecting staff morale on inpatient mental health wards in England: A qualitative investigation. BMC Psychiatry, 11. https://doi.org/10.1186/1471-244X-11-68.

Tunggal Wiranti, F. H., Priyono, A., dan Apriono, M. (2011). Pengaruh Kepemimpinan, Motivasi Kerja dan Kepuasan Kerja melalui Organizational Citizenship Behavior ( $O C B$ ) terhadap Kinerja Guru Sekolah Dasar Negeri Kecamatan Mayang Kabupaten Jember (The Effect Of Leadership, Job Motivation, And Job Satisfaction T.

Turcotte, P. R. (1988). La qualité de vie au travail: une voie vers l'excellence.

Wandary, W., and Umi Anisah, H. (2015). Organizational Culture Values Influences to Lecturer' s Organizational Citizenship Behavior at Economics and Business Faculty. Mediterranean Journal of Social Sciences, 6(5), 236-242. https://doi.org/10.5901/mjss.2015.v6n5s5p236.

Werang, B. R. (2014). Pengaruh Kepemimpinan Transformasional Kepala Sekolah, Moral Kerja Guru, Dan Kepuasan Kerja Terhadap Kinerja Guru SDN Di Kota Merauke. Jurnal Cakrawala Pendidikan, 1(1), 128-137. https://doi.org/10.21831/cp.v1i1.1869. 